\title{
István Bukovics
}

\section{The "Good State": Outline of the Last Three Years of Research}

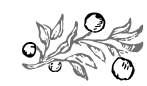

\section{Summary}

The vision behind the research aimed at the paradigmatic approach of a "Good State" can be summed up in a single sentence as follows: on the basis of the "Good State" concept, defined by the Magyary Programme, a theoretical state model can be elaborated using IT tools. The model determines certain generic concepts of the state, with mathematical and logical accuracy. Then they can be implemented in silico (i.e. with direct IT tools exceeding traditional mathematical concepts) and related fundamental statements can be proven. During our multi-year research we sought, and (partly) found, constructive answers to such (political and philosophical) questions as how it is possible to optimally satisfy the moral and teleological needs of a self-regulating, self-driven, self-organizing society by rational means (in a clearly defined sense). This programme cannot be realized merely on a judicial - jurisprudential, political and scientific - basis, a more exact scientific establishment is needed. The approach of political science is shaped by law, although there is an antagonistic contradiction between the approach of jurisprudence and that of exact sciences. We are looking for the answer to this question using a computer program. In contrast to the ambitions of the "Good State" Research Shop (GSR), we focus on a better understanding of the concept of a "Good State", while its measurement is beyond the scope of our research. We hope to improve understanding the concept of a "Good State" with the help of computer modelling and logical explication. Accordingly, this paper is an alternative to the GSR approach and the two methods can profit from each other and the "Good State" from both. Thus, we share the goal but have different methods.

Keywords: Good State, sustainability, Magyary Programme, public good, needs

Dr István Bukovics, DSc, Professor, National University of Public Service, Head of Doctoral School of Public Administration Sciences (bukovics.istvan uni-nke.hu). 


\section{INTRODUCTION}

This essay aims at surveying certain research results concerning the codification methods of the "Good State" on the basis of principles laid down in the interpretation framework of the Magyary Programme (KIM, 2012). These methods are characterized by the fact that they rely on basic mathematical and logical routine, while applying IT tools to improve understanding the Good State. We expect better understanding of the concept of "Good State" through computer modelling and logical explication.

Its aim is twofold: On the one hand the presentation and application of a pattern of thinking based on symbolic logic that serves, through processing legislative knowledge, as a reference framework, a model, a paradigm and a decision-making strategy for the concept of the Good State and (on that basis) its sustainability. Its theoretical conditions are included in the conceptual system of symbolic - or formal - logic.

Furthermore, its aim is to propose a definition and to evaluate valuable and interest-free indicators applicable in public administration and suitable for the characterization of sustainability and more precisely the given condition and sustainability of the Good State. Its technical preconditions are provided by direct, computer-based model creation - called in silico approach -, which also this expands the theoretical toolbox.

Thus it attempts at laying the scientific foundations of all the activities of the State which characterize the conditions of a Good State (in other words, the good condition of a state) precisely (in a formal and exact way), facilitate its evolution and ensure its sustenance. The applied method is IT (computer-based, in silico) model generation.

On the other hand: another aim of this paper is to contribute to the exact theory of the Good State. A critical evaluation is given of definition of the "Good State" (as given in the Magyary Program), it is clarified, and the foundations of a theoretical model for an in silico sustainable state are elaborated.

The Magyary Programme gives the definition of the "Good State" as follows: "A state is considered to be good if it serves the needs of individuals, communities and enterprises in the interest and within the bounds of public good in the most appropriate manner."

The definition of public good includes the following:

- The state creates a balance between the countless interests and needs in an equitable and fair way, and for this end it ensures claims enforcement and provides protection;

- The state proceeds with proper responsibility to protect and pass on inherited natural and cultural goods;

- The only self-interest of the state is to be able to enforce the two previous elements of public good under all circumstances and efficiently, that is, the state creates an efficient rule of law, including functioning institutions, respect for the rights of individuals and communities, and accountability.

The most appropriate manner may result in different emphases on different areas 
of state operation, since on the one hand efficiency and national interest are the main catchwords in public administration, and on the other hand, in jurisdiction the power of the enforceable right and equitableness are the primary considerations, naturally, with the proviso that these expectations are mutually made in the other sector.

In the period of a world economic crisis and markedly narrow resources, it should be highlighted that universal absolute good can hardly be achieved at a state level, even if the individual community interests are met exclusively, no matter how emphatic they are. Most significant failures in the development of the historical Hungarian state happened because the state followed, allowed or led movements determining the aim and frame of its operational objectives in the wrong direction or at the wrong pace. This historical experience, the democratic electoral expectation and conscious self-development of the state justify the need for the complete cognizability, measurability and evaluation of the state and its operation.

It is an evolutionary outcome that for the majority of people unknown things are frightening, that is in no case necessarily good. The Good State is cognizable, its citizens can find their ways about it, and therefore the step preceding the first one is to describe and present what we mean by "good" and "easily understandable".

\section{GUIDELINES}

This paper is based on the following guidelines:

- All the rules have to be in harmony with the system of criteria for a Good State, as it is laid down in the Magyary Programme. This is why it is - directly or indirectly (in the figurative and colloquial sense of the words) - included in the common part of all laws.

- The concept of the Good State, as laid down in the 2012 Magyary Programme, can be explicated. This means that it is definitely decidable by means of exact mathematical and logical means whether the joint existence or absence of the risk factors within the scope of law enforcement ${ }^{1}$ is a necessary and sufficient condition of the achievement of the Good State.

- The analysis of the economic, financial and political effects of any logically possible tightening and loosening (as defined exactly below) of the explicated juridical representation of the Good State (understood in the above-specified way) can be theoretically described.

The first level verbal explication ("professional declaration", "fault tree", "explicative reading") of the supposed juridical representation of the Good State on the basis of the concept of the Magyary Programme, according to the paradigm of the logical risk theory, see (Bukovics, 2007) is, in my view, as follows: Any state is good if, and only if, the following conditions are satisfied:

(1) It serves the needs of individuals in the interest of the public good in the most appropriate way.

(2) It serves the needs of individuals in the frame of the public good in the most appropriate way. 
(3) It serves the needs of communities in the interest of the public good in the most appropriate way.

(4) It serves the needs of communities in the frame of the public good in the most appropriate way.

(5) It serves the needs of enterprises in the interest of the public good in the most appropriate way.

(6) It serves the needs of enterprises in the frame of the public good in the most appropriate way.

The question is: How is a Good State created (at least in principle, as a logical consequence of something that we do not know but want to know) merely by the satisfaction of needs (in the interest and in the frame of the public good)? The Magyary Programme gives the cleverest possible answer to this question. The Good State is by definition the state satisfying needs. (The state, according to the Magyary Programme, "becomes good if" its operation satisfies needs.). As for me, I consider this answer as mere demagogy. Following a proper definition of the concept of the "public good", I prove that the satisfaction of needs logically entails public good.

\section{BASIC DEFINITIONS AND ASSUMPTIONS}

On the definition of sustainability: Sustainability and sustainable development are very trendy, frequently used, partly discredited concepts. Their essence is the ambition to permanently follow a development trajectory without exhausting the reserves and opportunities of subsequent modes of existence. The principal problem with the interpretation of sustainability is that currently decision-makers widely use the term for simply following the trajectory marked out by them and eliminating any obstacles that get in their way. This is how the concepts of "sustainable development" or "sustainable mobility" are made, in Hungary and abroad, with content that has little to do with the original concept of sustainability. In contrast to this, sustainability is meant to express that objectives must not be freely chosen in any dimension or sector, rather - due to complicated system correlations - they should remain within certain boundaries.

In addition to the above, recent debates have concerned the concepts of development and growth. The term "science of sustainability" was coined to relieve tension. In essence, its message is for the poor is to let everybody share at least as much as needed for basic human needs, while for the rich the implication is to adopt more modest and more economical lifestyles and consumption habits.

If we are to analyse the concept of sustainability in the context launched in the book The Limits to Growth, published on the initiatives of the Club of Rome and explained in the Brundland Report entitled Our Common Future, then out of the two fundamental semantic contents of the word "sustainability", we have to reject "sustainable development" to the benefit of "sustainable function" (manner of operation, manner of existence, quality of life). As an example let us highlight the state and its operative system, public administration, since sustainability processes are implemented primarily through the latter. 
As a starting point we accept the fact that analysing sustainability in this sense means to examine the necessary and sufficient conditions of sustainability. It is insufficient to examine sustainability itself. Social expectations require feasible and practical methods (procedures, techniques, laws, strategies) for the maintenance of global functions. How maintaining the functions of a system can be technically grasped (including the entire human society and all its essential concerns)? In our opinion through suitable institutions and actions.

The concepts "institution" and "action" are not exact enough to allow treatment by strictly theoretical means (especially by mathematical logic and information technology). Colloquial language is completely unsuitable for this purpose, and even the technical lingos of public administration or jurisdiction are inappropriate.

Thus a satisfactory answer to the general question of how to maintain system operation can only be given if it also includes information on the operation of the institution and the way of the measurement. In this regard we can hardly say more than the system (that must be functionally maintained) should work well to ensure that suitable measures serve the elimination of undesirable events concerning the system. In this context we may replace the term "well-functioning" by "acceptable". A system is acceptable if its undesirability can be refuted. When can a system be considered to work well? In our opinion, not in a faultless condition (although logically faultless function is of course a sufficient condition of well-functioning). Since, however, such systems do not exist (and according to certain approaches it is proven that they cannot exist), for a substantive answer to this question only one possibility is left: institutions should be established and actions should be taken for the permanent handling of system dysfunctions. Dysfunction management means prevention and/or aversion of undesirable events (Bukovics, 2013).

It follows from the above that the theoretical foundation of functional sustainability requires the elaboration of a theory that does not proceed from describing processes (whether natural or artificial) but defines rules and actions which must be observed and implemented under given circumstances to achieve the objective set. In other words, a normative rather than a descriptive theory is expedient. For merely technical purposes I call the model used for this theory a "game model" and describe it as follows.

\section{THE GAME MODEL}

\section{State and Market}

The model considers the legislative process as a game between the "State" and the "Market". The State is a risk system. Risk systems cannot exist without risk factors. The "Market" is the IT representation of the risks of the state.

The game is modelled as a sequence of steps made alternately by the two players. A step is a sequence of actions performed by one of the parties and made between two consecutive actions of the other party. 


\section{Logical risk analysis: fault tree method}

The classical method of a "probabilistic risk analysis" has been modified and given the name "logical risk analysis" (Bukovics, 2007). The negation of Good State is considered as the core (undesirable) event. This means that the non-satisfaction of the system of necessary and sufficient assumptions must be analysed, i.e. the non-satisfaction of any of the assumptions leads to non-accomplishment of the Good State (more precisely, of the good condition of the state). Negation of the assumptions appears in the juridical representation of the Good State in an or form, i.e. in a disjunctive relation.

An adaptive codification is possible because conjunctive and disjunctive relations equally occur in the course of the iterative explication of the system of assumptions. From the point of view of jurisdiction, transforming a conjunctive group of assumptions into a disjunctive one means tightening, while transforming a disjunctive group of assumptions into a conjunctive one means loosening (Bukovics, 2007; 2015).

\section{Strategies and tactics}

The direct aim of the "State" (of course merely in the model) in all cases is to passivize the active fault tree (core event). The expression "active fault tree" is a technical term which means that the system is in a micro-state condition, with the logical consequence that the "Not a Good State" statement proves to be mathematically true.

The State (due to the basic hypotheses of the model) does not have the option to change the micro-state, because it depends on the behaviour of the "Market". Due to the underlying hypothesis of the model, the State does not intervene into the processes of the market.

One of the variants of the explicate of the basic legal rule may be as follows:

The State is not in a good status if and only if

(1) It serves the needs of individuals in the interest of public good not in the most appropriate way, or

(2) It serves the needs of individuals in the frame of public good not in the most appropriate way, or

(3) It serves the needs of communities in the interest of public good not in the most appropriate way, or

(4) It serves the needs of communities in the frame of public good not in the most appropriate way, or

(5) It serves the needs of enterprises in the interest of public good in the most appropriate way, or

(6) It serves the needs of enterprises in the frame of public good not in the most appropriate way.

A logical modification of this explicate may be the following:

The State (is) not in (a) good (status) if and only if

(1) It serves the needs of individuals in the interest of public good not in the most appropriate way, or 
(2) It serves the needs of individuals in the frame of public good not in the most appropriate way, or

(3) It serves the needs of communities in the interest of public good not in the most appropriate way, and

(4) It serves the needs of communities in the frame of public good not in the most appropriate way, or

(5) It serves the needs of enterprises in the interest of public good in the most appropriate way, or

(6) It serves the needs of enterprises in the frame of public good not in the most appropriate way.

"Logical modification" means that the logical type of an explicate /in this present case under section (3)/ is changed, so the disjunction (indicated by the word "or") is changed to a conjunction (indicated by the word "and"). The synonym of "logical modification" is "operation changing step".

The provable consequence of the model is that in the general case one single operation changing step may not result in the head event becoming passive (passivating). It is especially striking when - as in the paper (Bukovics, 2013) - if the original (operation) chain OAAAAAAAAAAAAAAAAAA (that is, in which the one single component is disjunctive) is effective. Since it cannot be unmitigated, because its only possible mitigation is the clear AAAAA...A, it leads to a chain which is justifiable by calculation: quorum-free, so it is not applicable for legitimation by voting.

\section{The State Substratum model}

The State Substratum model is a model construction (a computer program), which allows the study of society and the most elementary manifestations of the state in a trustworthy (verifiable) way. The State Substratum is formally a cellular automation model (Wolfram, 2002). The State Substratum model is a neighbouring cell automation (Riguet, 1976). The number of elements is (cells) $\mathrm{N}=2^{16}(=65$ 736). The number of stages is $\mathrm{n}=16$. Each element has four neighbours. The transition function is "majorant copying" ${ }^{2}$. Its precise mathematical definition has been given in hundreds of publications since Neumann (Neumann, 1966). In this case the emphasis is not on the theoretical construction, but on its interpretation, on the study and introduction of the emergent ("emerging from nothing") structures and functions facilitating the better understanding of the creation of the state concept model (moreover, even its modifiability, see Koronváry, 2009:30, 58, 64).

The State Substratum model is a structure in which an opportunity (but not a necessary fulfilment) is provided for each agent, without an exception, that make the state (individuals, institutions, organizations) to satisfy their needs. The question- and in this study a fundamental question - is whether such a system is capable of self-organization, especially of a beneficent, improving, self-developing and self-perfecting development. If yes, it should reasonably be taken into consideration in the theory and practice of the state. 
In the State Substratum model, the state (its substratum) consists of the population of individuals (agents) and cells, respectively, in - at the moment - interchangeable roles. Satisfaction of the needs of each single individual (cell) is manifest in the fact that if in its neighbourhood there is another individual that exceeds its condition by at least a minimum, then (and only then) the individual takes (copies, replicates) this stage. In short, the individual "converges" or closes the gap.

This is to model - in the first approach - the satisfaction of a need.

Chaos (in this case the random population) is capable of a very intensive selforganization. The lesson is that disorder - which seems to be most unmanageable and therefore most unreliable concept - can form the logical basis of the most exact concepts. To this end, it is sufficient to force chaos (by a simple iteration) to follow only one rule: the majorant rule. Its apparent content is: the job of the state is - above all and pre-eminently - to satisfy the demands (justified needs) of its citizens and to ensure the satisfiability of these demands.

\section{THE NEED FOR PARADIGM CHANGE}

The aim of the State Substratum model is to demonstrate how the model theoretically responds to random effects. In this model the "State" and the "Market" are abstractions. The "Market" is the set of risk factors disturbing the operation of the "State" as a risk-assuming agent. The model describes the interaction of these two abstract entities. Its interpretation is the behaviour of the State represented in the model by a random number generator. The presumed decisions of the State is modelled by the logical types of the variants of statutory regulations.

The model application constituting an inseparable part of the model (software package ${ }^{3}$ ) determines the counteraction of the "State" in response to each d-step of the "Market", i.e. to each micro-state which is at a d-distance from the dangerous micro-zone. The aim of the counteraction is always the designation of a passive (macro-state) Principal Chain.

Due to the plurality of interpretation inherent in the nature of the subject, there may be parallel paradigms in social sciences. It follows from this, that the problem of the Good State demands a paradigm shift. ${ }^{4}$

The catchwords Change-Effect-Response pave the way to the automation theory, which - combined with the in silico information technology - offers the new paradigm. Disregarding a narrow, specific interpretation of the Change-Effect-Response project (environment protection, climate-strategic, climate political etc.), it is promptly clear that the Change-Effect-Response concept easily translates into modelling the operation of the State.

\section{Change}

In this model, the concept of change is interpreted as change in the micro-state of a system, and the micro-state of a system is defined as the total of the active prime events in the fault tree of the system. 
If the state is in a passive macro-state and there is no change in the micro-state (output of prime events) then the State does not change its macro-state, therefore no new legislative proposal of the State will replace the actual law.

A change in the micro-state has a significant and exceptionally complicated, often, counter-intuitive effect. The theory can and wishes to give a fair reconsideration of this phenomenon.

\section{Effect}

An effect analysis is conducted if the micro-state changes. As a first step, this includes the careful differentiation of four fundamental concepts, and decides which of the following (2.1-2.4) disjoint cases comes true:

- Partial macro-state deterioration: Due to the effect of the micro-state change, the (undesirable) core event (of the fault tree) of the system turns from passive into active and certain indicators of the state deteriorate while others improve.

- Partial macro-state improvement: Due to the effect of the micro-state change, the (undesirable) core event (of the fault tree) of the system turns from active into passive and certain indicators of the state improve while others deteriorate certain indicators of the state improve, others deteriorate.

- Total macro-state improvement: Due to the effect of micro-state change, the (undesirable) core event (of the fault tree) of the system turns from active into passive and each indicator improves or at least does not deteriorate.

- Total macro-state deterioration: Due to the effect of micro-state change, the (undesirable) core event (of the fault tree) of the system turns from passive into active and each indicator deteriorates or at least does not improve.

\section{Response}

The response given to the effect of a micro-state change is always the result of some kind of a decision. A rational decision is made if, due to a micro-state change, the multioptimal passive macro-state is in place. This means a passive macro-state, which is the supremum of itself. Verifiably there are always micro-states for which, in principle, it is impossible to respond with a passive legal macro-state.

At this point a political decision is made. This means that the algorithmic theory of legislation does not make the political decision unnecessary, but proves exactly its necessity, helps the decision maker to attain the learned intuitive level, where the limits of constrained rationality can be treated. It proves furthermore the importance and place of manual control against that in political rhetoric the phrase "manual control" is generally burdened with a negative connotation.

This theory gives a kind of method to reveal the correct relation of manual and mechanical control, so the complementing relation of objective and subjective decision. 


\section{Multi-OPTIMALITY}

In the game model the realization of "Good State" always means the passivation of the core event of the fault tree corresponding to the actual law variant. This happens through the passivation of one of the strong points (more exactly: of all prime events of the given strong point). Each prime passivation obviously has an expense and time need. Since these change from prime to prime, it does matter, whether the cheapest (which is the one with the smallest cost), the fastest (which is the one with the smallest time need), or the shortest (which contains the fewest prime events) strong point is passivated.

The fundamental question arises: the question of multi-optimality. In order to formulate the question we have to introduce a new term, the concept of Franklin indicators. "Franklin indicators" is the collective name for the passivation costs and time of the cheapest, fastest and shortest strong points, respectively.

The fundamental question of the multi-optimality of Franklin indicators is, whether there exists a law variant whose all Franklin indicators belonging to its operation chain are minimal.

The game model and its theory results in the main statement that the answer is "yes".

\section{OUTLOOK}

In this model the specific property of the problem - as against the general practice of fault tree method - is that here prime events cannot be connected to events, activities falling within our competence (so within the competence of the state). In this case the outcome of the prime event depends on an abstract "Market" entity supposed to be rather ideal typical. Concerning this we supposed only that the events of the Market, as risk factors of the operation of the State, are functioning as failure sources.

At the moment we have no operable explanation relating to how we could attach cost and duration to the prime events of the Market in a reasonable and measurable way.

\section{Notes}

1 The definion of a risk factor falling within the scope the law enforcement should not be confused with the concept of a risk factor belonging to the competency of law enforcement.

2 AIM-SORS modell, lásd Bukovics, 2007.

3 More details are available on the application on the following mail address: bukovics.istvan@uni-nke.hu. The user guide of the application includes the necessary theoretical base.

4 The concept of "paradigm" is used in such a meaning how I expressed it in my thesis (Bukovics, 2007, Section 1.5, 19). 


\section{REFERENCES}

Bukovics, István (2007): A természeti és civilizációs katasztrófák paradigmatikus elmélete. MTA-doktori értekezés, Budapest.

Bukovics, István (2013): A fenntartható közigazgatás elmélete. Polgári Szemle, Vol. 9, No. 3-6.

Bukovics, István (2015): A ,jó állam” algoritmikus elmélete. Polgári Szemle, Vol. 11, No. 1-3.

KIM (2012): Magyary Zoltán Közigazgatás-fejlesztési Program (MP 12.0). Közigazgatási és Igazságügyi Minisztérium, Budapest.

Koronváry Péter (2009): Rendszertan. ZMNE, Budapest.

Neumann, John von (1966): The Theory of Automata. In: Theory of Self-Reproducing Automata. Ed. Arhur W. Burks, University of Illinois Press, Urbana-London.

Riguet, Jacques (1976): Automates cellulaires a bord et automates Codd-ICRA. Comptes Rendus de l'Academie les Sciences de Paris. Magyarul: Sejtautomaták. Szerk. D. Takács Viola, Gondolat Kiadó, Budapest, 1978. Wolfram, Stephen (2002): A New Kind of Science. Wolfram Media, Champaign. 